Progress. His post-operative course was satisfactory and he was discharged on June 15th, 1962-seven weeks after admission. On the second post-operative day the blood pressure was $170 / 120$, on the fourth it was $160 / 105$, and by the eleventh day (on discharge) the reading was $135 / 90$. On June 8th, 1962, intensive antituberculous therapy was started: streptomycin sulphate 0.5 g. b.d. for six weeks, para-aminosalicylic acid $10 \mathrm{~g}$. each day and iso-nicotinic acid hydrazide $200 \mathrm{mg}$. each day for eighteen months.

Follow-up. When examined on February 19th, 1963, ten months after the operation, he had no complaint. He had no symptoms referable to the urinary tract. His appetite was good and his weight had increased by $10 \mathrm{lb}$. (4.4 Kg.). B.P. $120 / 80$, X-ray examination of the chest showed no active lung disease and the cardiac shadow was normal. ECG normal. Urological examination on May 15th, 1963, showed a normal bladder, and on retrograde pyelography a normal left kidney.

In August, 1964, more than two years after operation, the patient continued to be symptom-free. The blood pressure was $150 / 90$ and the electrocardiogram was normal.

\section{Comment}

Hypertension is not a common occurrence in renal tuberculosis. In more than a thousand cases of renal tuberculosis treated by one of us (W.B.) this is the first occasion on which co-existing hypertension has been relieved by nephrectomy.

The patient has been under observation for two years since the operation was performed. The blood pressure remains normal. There is no clinical evidence that the remaining kidney suffered damage during the period preceding surgical intervention. It is, of course, impossible to say how long the hypertensive state had lasted. From the nature of the tuberculous lesions it can be surmised that the kidney had probably been a non-functioning organ for many months-and perhaps for a year or two; and during most of this time there was probably some degree of hypertension.

We are grateful to Professor S. Alstead for permission to publish this case, to Dr. S. Haase for the X-ray examinations and to Dr. G. Slavin for his interpretation of the morbid anatomy.

\section{REFERENCES}

MANOR, E. (1962): Amelioration of Asthma and Hypertension after Nephrectomy for Renal Tuberculosis, J. Urol (Baltimore), 87, 767.

\title{
RENAL PAPILLARY NECROSIS AND PHENACETIN: TWO FURTHER CASES
}

\author{
AleXander KenNedy, M.D. \\ Department of Pathology, University of Liverpool.
}

THE CONNECTION between phenacetin abuse and renal disease was postulated by Spuhler and Zollinger (1953) but reports of this association were confined to the Swiss and Scandinavian literature until 1960. The first case to be described in the United States was that of Moolten and Smith (1960) and the number of American cases reached 18 by 1964 . An enquiry by Friend (1963) suggested that many cases, as yet unpublished. were known to American urologists. The findings of the European workers received substantial support from Australia in 1962 when Jacobs and Morris reported a study of 47 cases of renal papillary necrosis occurring in phenacetin takers; simultaneously, another six cases were published by McCutcheon (1962). Some authorities have questioned the importance of the role of phenacetin in the causation of renal disease but recently it has been shown that this compound can cause papillary necrosis in the rat (Abrahams, Rubenstein, Levin and Wunderlich, 1964).

No case of renal papillary necrosis due to phenacetin had been described in the United
Kingdom until recently (Sanerkin and Weaver, 1964). The ensuing correspondence, in the British Medical Journal, revealed two more cases (Sanerkin, 1964; Jacobs, 1964) and a further case has been described by Scott (1964). The present paper described two cases seen in Liverpool during the last year. This brings the total of British cases to six and indicates that this condition may be more common in this country than the literature suggests.

\section{Case Reports \\ Case No. 1}

This woman was admitted to hospital for the last time in November 1963 when she was aged 66 years. She had suffered from arthritis for 37 years and had received a course of gold injections when she was aged 40 years. At the age of 53 hysterectomy was performed for carcinoma of the body of the uterus. In 1952, when she was aged 56, it was noted that she was taking compound codeine tablets for the relief of her joint pains. In 1955 she had a course of treatment with phenylbutazone and in the following year a short course of steroid therapy was tried but 


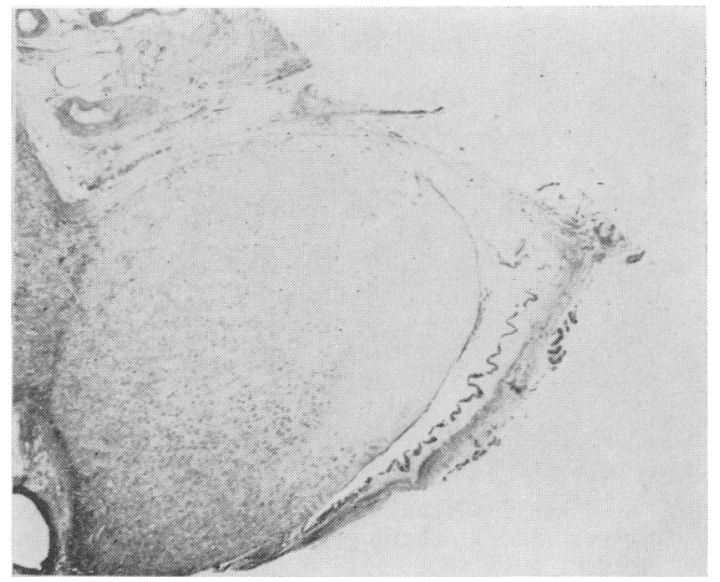

FIG. 1.-CASE 1: Necrosis of the tip of the renal papilla. H \& E $\times 5$.

this was without significant benefit. She was diagnosed as suffering from a generalized polyarthritis of osteoarthritic type and at this time it was recorded that she was taking at least six compound codeine tablets (B.P.) and eight aspirin tablets per day. This regime would involve a daily intake of $4 \mathrm{~g}$. of aspirin and $1.5 \mathrm{~g}$. of phenacetin. Her urine was normal and her blood pressure was 180/90.

She was admitted to hospital in 1962 (aged 65) complaining of diverse symptoms. She was in mild congestive cardiac failure with atrial fibrillation and a blood pressure of $180 / 100$. After digitalization and a period of rest she was discharged but she continued to consume a large number of codeine tablets.

At her final admission, in 1963, she was extremely ill and complained of a cough, pain in the chest and intractable vomiting. She was oliguric and a pericardial friction rub was audible. Her blood urea was $325 \mathrm{mg}$. $/ 100 \mathrm{ml}$., her carbon dioxide combining power was only $25 \mathrm{ml} . / 100 \mathrm{ml}$. of serum and her serum potassium level was $6.3 \mathrm{mEq}$./L. A small quantity of urine was passed, this contained neither protein nor blood but its urea concentration was only $0.9 \mathrm{~g} . / 100 \mathrm{ml}$. She died three days after admission.

Necropsy. Performed six hours after death. There were arthritic deformities of the interphalangeal joints and oedema of the ankles and sacrum.

There were bilateral pleural effusions and a fibrinous pericarditis with effusion. The heart weighed $550 \mathrm{~g}$. and showed hypertrophy of the left ventricle but no significant lesions of the valves or coronary arteries. The kidneys were of normal size but the cortices were very pale and finely granular. The tips of the renal pyramids were cyanotic in colour and appeared necrotic even to the naked eye. There was no macroscopic evidence of pyelonephritis or of obstruction to the urinary tract.

Histology. The most striking feature was the necrosis of the tips of the papillæ; the terminal collecting ducts were dilated and contained granular debris and the epithelium over the papillæ was necrotic (Fig. 1). The mucosa of the pelvis was not thickened and was not infiltrated by inflammatory celis.

The cortex of the kidney showed extensive intertubular fibrosis; a very few lymphocytes (Fig. 2),

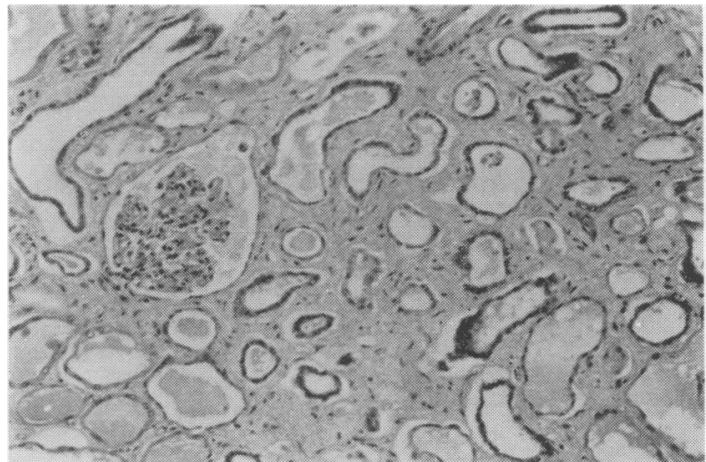

FIG. 2.-CASE 1: Renal cortex showing intertubular fibrosis without inflammatory reaction. H \& E $\mathrm{x} 85$.

were present in the fibrous tissue. The basement membranes of many of the tubules were grossly thickened and lipofuscin was present in some of the cells. No calcium oxalate crystals were seen. Some of the glomeruli were hyalinised and there was marked hypertensive change in the arteries.

\section{Case No. 2}

This man, aged 70 years, began to vomit and lose weight in May 1964. A provisional diagnosis of carcinoma of the stomach was made but the patient died at home before admission to hospital could be arranged.

Necropsy. At the request of the coroner, a post mortem examination was made, six hours after death. There was marked pulmonary oedema. The heart showed no lesions of the valves or coronary arteries and weighed $360 \mathrm{~g}$. The only significant findings were in the kidneys which were small and pale and weighed only $40 \mathrm{~g}$. each. The capsule was adherent and the cortex was granular. There was no sign of either pyelonephritis or urinary obstruction but the papillæ were obviously necrotic.

In view of the nature of the terminal illness and the pathology of the kidneys, it was considered that death was probably due to uræmia caused by papillary necrosis. Subsequent enquiry revealed that the patient had been troubled by "sciatica" for many years and had treated himself with compound codeine tablets. His widow knew that he had taken two tablets night and morning for the last two years and thought that he may have taken tablets during the day. This would have provided a dose of at least $1 \mathrm{~g}$. of phenacetin per day.

Histology. In this case there was a very obvious necrosis of the whole of each papilla but there was no evidence of acute inflammation (Fig. 3). The collecting ducts were distended with debris and, in some areas, the necrotic papillæ were calcified. The renal cortex was much more severely damaged than in Case 1 but, as there was considerable thickening of the arteries, much of this damage may have been vascular in origin. The cortex was narrowed and there was extensive fibrosis and infiltration by lymphocytes. Many of the glomeruli were hyalinised and the basement membranes of the tubules were thickened (Fig. 4). Granules of lipofuscin were present in some of the cells and in some areas of the cortex there were crystals which were probably calcium oxalate (Scheidegger, 1958). 


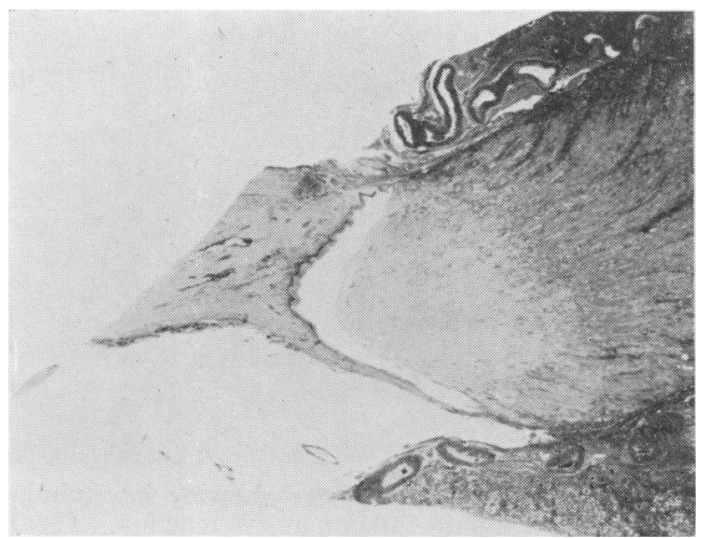

FIG. 3.-CASE 2: Extensive papillary necrosis. The pelvic epithelium is normal. $\mathrm{H} \& \mathrm{E}$ x.5.

\section{Discussion}

The world literature on this subject has been reviewed by Ross (1962) Friend (1963) and Zeman (1963). The two cases here described have features in common with each other and with the series of cases already published.

Both patients presented with a short terminal illness characterized by vomiting. In one case the terminal event was uraemia and it is probable that this was so in the second case also. Both cases had renal papillary necrosis and interstitial fibrosis of the renal cortex. It is probable that some of the cortical changes were vascular in origin but in neither case was there any evidence of pyelonephritis, diabetes or urinary obstruction, all of which are factors known to be able to cause papillary necrosis (Hultengren, 1961).

There was a history of the regular consumption of compound codeine tablets over a period of at least twelve years in one case and two years in the other. The first case had probably consumed at least $7 \mathrm{~kg}$. of phenacetin and the second case at least $0.7 \mathrm{~kg}$. but in this second case only an incomplete history could be obtained. In his review, Ross (1962) found that the total phenacetin consumption in the published cases varied between $0.5 \mathrm{~kg}$. and $65 \mathrm{~kg}$. over a period of between two and thirty-eight years. Schweingruber (1955) considered that an intake of more than $0.9 \mathrm{~g}$./day would be dangerous if continued for over one year. On the basis of these figures it is clear that both the present cases had consumed dangerous quantities of phenacetin.

\section{Summary}

This paper describes two fatal cases of renal papillary necrosis in patients who had taken compound codeine tablets habitually. Death was due to uraemia in one case and probably due to uraemia in the second. Both cases showed necrosis of the renal papillae without evidence of pyelonephritis or urinary obstruction. The pathological findings were similar to those described in the previous literature.

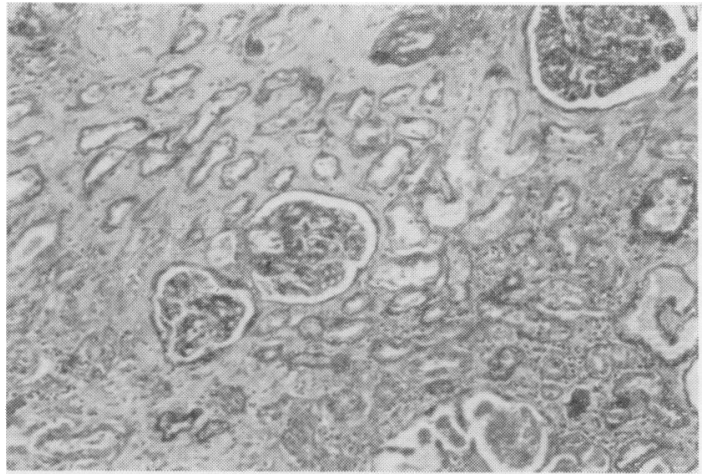

Fig. 4.-Case 2: Renal cortex showing intertubular fibrosis and thickening of the basement membranes. PAS x85.

I wish to thank Professor H. L. Sheehan for his helpful criticism and $\mathrm{Mr}$. A. C. Hemes for the photography. I also wish to thank Dr. E. T. BakerBates for permission to publish Case 1 and H.M. Coroner for the City of Liverpool for permission to publish Case 2.

\section{REFERENCES}

Abrahams, C., Rubenstein, A. H., Levin, N. W., and WUNDERLICH, V. (1964): Experimentally Induced Analgesic Nephritis in Rats, Arch. Path., 78, 222.

FriEND, D. G. (1963): Analgesic Abuse and Renal Toxicity, J. Amer. med. Ass., 184, 495.

Hultengren, N. (1961): Renal Papillary Necrosis: Clinical Study of 103 Cases, Acta chir. scand. Suppl., 277, 1 .

JACOBS, H. S. (1964): Phenacetin Abused, Brit. med. J., i, 1381.

JACOBS, L. A., and Morris, J. G. (1962): Renal Papillary Necrosis and Abuse of Phenacetin, Med. J. Aust., ii, 531.

McCutcheon, A. D. (1960): Renal Damage and Phenacetin, Ibid, ii, 543.

Moolten, S. E., and Smith, I. B. (1960): Fatal Nephritis in Chronic Phenacetin Poisoning, Amer. J. Med., 28, 127.

Ross, P. (1962): A.P.C. as a Cause of Renal Disease, Med. J. Aust., ii, 539.

SANERKIN, N. G. (1964): Phenacetin Abused, Brit. med. J., i, 980.

SANERKIN, N. G., and WeAver, C. M. (1964): Chronic Phenacetin Nephropathy ("Chronic Interstitial Nephritis") with Papillary Necrosis, Brit. med. J., i, 288.

SCHEIDEGGER, S. VON (1958): Pathologisch-anatomischer Beitrag zur Frage der Chronischen Interstitielen Nephritis im Anschlub an Abusus von Phenacetinhaltigen Analgetica, Bull. schweiz. Akad. med. Wiss., 14, 139.

SchWEInGRUBER, R. (1955): Probleme der Chronischen Vergiftung mit Kombinierten Phenacetinpraparaten, Schweiz med. Wschr., 85, 1162.

ScotT, J. T. (1964): Renal Changes Associated with Analgesic Drugs, Lancet, i, 827.

SPUHLER, O., and Zollinger, H. U. (1953): Die Chronisch-interstitielle Nephritis, $Z$. klin. Med., 151, 1 .

Zeman, F. D. (1963): Toxic Effects Ascribed to the Prolonged Use of Phenacetin, J. chron. Dis., 16, 1085. 